Article

\title{
A Fructan Sucrase Secreted Extracellular and Purified in One-Step by Gram-Positive Enhancer Matrix Particles
}

\author{
Jingyue Wang, Huazhi Xiao, Fangkun Zhao, Bo Zhao, Min Xu, Zhijiang Zhou and Ye Han *
}

Citation: Wang, J.; Xiao, H.; Zhao, F.; Zhao, B.; Xu, M.; Zhou, Z.; Han, Y. A Fructan Sucrase Secreted Extracellular and Purified in One-Step by GramPositive Enhancer Matrix Particles.

Processes 2021, 9, 95. https://doi.org/ $10.3390 /$ pr9010095

Received: 26 November 2020 Accepted: 31 December 2020 Published: 5 January 2021

Publisher's Note: MDPI stays neutral with regard to jurisdictional clai$\mathrm{ms}$ in published maps and institutional affiliations.

Copyright: (C) 2021 by the authors. Licensee MDPI, Basel, Switzerland. This article is an open access article distributed under the terms and conditions of the Creative Commons Attribution (CC BY) license (https:// creativecommons.org/licenses/by/ $4.0 /)$.
School of Chemical Engineering and Technology, Tianjin University, Tianjin 300350, China; wangjingyue0802@163.com (J.W.); xiao@tju.edu.cn (H.X.); zhaofkk@163.com (F.Z.); zhaobo1995@tju.edu.cn (B.Z.); minxu@tju.edu.cn (M.X.); zzj@tju.edu.cn (Z.Z.)

* Correspondence: hanye@tju.edu.cn; Tel.: +86-22-27403389

\begin{abstract}
Fructan sucrase is a kind of biological enzyme that catalyzes the synthesis of fructan, and fructan is a polysaccharide product with important industrial application value. In this study, the Fructan sucrase gene of Bacillus subtilis was cloned to plasmid PET-28A-ACMA-Z, and three clones were obtained after the transformation of Escherichia coli BL21, namely BS-FF, BSO, and BS. The clones BS-FF and BSO secreted the recombinant enzymes outside the cells, while the clone BS expressed them inside the cells. The induction experiment results showed that the optimum IPTG concentration in the medium was $0.5 \mathrm{mM}$ and $1.0 \mathrm{mM}$ for clones BS-FF and BSO, respectively, while the incubation conditions were at $28^{\circ} \mathrm{C}$ for $8 \mathrm{~h}$. The recombinant fructan sucrase was purified one step using a material called GEM particles. The results indicated that $95.25 \%$ of fructan sucrase expressed by the clone BS-FF could be secreted into the extracellular area, and even $98.78 \%$ by the clone BSO. With the above purification system, the receiving rate of the recombinant enzyme for clones BS-FF and BSO was $97.70 \%$ and $84.99 \%$, respectively. As for the bioactivity of recombinant fructan sucrase, the optimum temperature and $\mathrm{pH}$ were $50{ }^{\circ} \mathrm{C}$ and 5.6 , respectively. The $\mathrm{Km}$ and Vmax of it were $33.96 \mathrm{~g} / \mathrm{L}$ and $0.63 \mathrm{~g} /(\mathrm{L} \cdot \mathrm{min})$, respectively. The engineered strains with the high extracellular secretion of fructan sucrase were constructed, and a one-step method for the purification of the recombinant enzyme was established. The results might provide a novel selection for the enzymatic production of fructan on a large scale.
\end{abstract}

Keywords: fructan sucrase; Bacillus subtilis; secretory expression; Escherichia coli

\section{Introduction}

Recently, lots of health-promoting properties have been reported for fructans, including antioxidant activity, enhancement of the intestinal immune response, promotion of the growth/activity of beneficial colonic lactic acid bacteria, low caloric value, anticancerous, hypercholesteremic, and enhanced calcium absorption properties [1-4]. Meanwhile, fructans are widely used in pharmaceutical, food, textile, detergent, and other industries, such as anti-tumor agents [5]. Fructans can be used as non-digestible sweeteners, dietary fiber, and prebiotics in the food industry [6,7]. However, fructan is a functional oligosaccharide that is rare in nature and difficult to synthesize chemically. Microbial biosynthesis is mainly applied for the industrial production of fructans in recent years. Microbial enzymes in industrial applications have many advantages over plant enzymes and animal enzymes because they can be efficiently mass-produced. Meanwhile, higher product yield can be obtained at a relatively low cost [8]. The production of fructan mainly involves biosynthesis by microorganisms with sucrose as the raw material or by fructan sucrase enzymatic synthesis. Studies have shown that enzyme catalytic technology has great potential in the food field. [9]. However, only a few of the microorganisms that have been found to be able to produce fructan produce the enzyme at a high capacity, severely limiting the large-scale industrial production and application of fructan. Therefore, the production of fructan by using biological enzyme engineering technology has become 
the main production method, and the mass production, purification of high-efficiency fructan sucrase has become the focus of these studies. Fructan sucrase performs three different catalytic functions, polymerization, hydrolysis, and transfructosylation, and these functions depend on the kind of acceptor molecule used by the enzyme [10]. Many studies have indicated that fructan sucrase is present in Clostridium acetobutylicum [11], Lactobacillus reuteri [12], Bacillus licheniformis ANT 179 [13], and Leuconstoc mesenteroides Lm 17 [14]. Ishida Ryuichi et al. [15] cloned and expressed fructan sucrase from L. mesenteroides NTM048, a probiotic strain with immunomodulatory activity, and purified the enzyme. Liu, Qian et al. [16] identified a new fructan sucrase capable of producing fructan from Brenneria goodwinii. In the above studies, the fructan sucrase was expressed and purified with a $\mathrm{Ni}^{2+}$-charged HisTrap HP column (GE Healthcare), which bound the His6-tagged LvnS protein, to obtain pure fructan sucrase. This purification method has many disadvantages, such as high cost, long time, and low efficiency. Moreover, extracellular proteins that strongly facilitate downstream processing in industrial production and thus reduce production costs are preferred. Whether in theory or industrial production, the extracellular secretion of protein has enormous advantages over traditional protein production. Secretion of proteins is highly needed to produce large amounts of protein, as it avoids the need for cytoplasmic proteases, facilitates proper folding, minimizes purification steps, and reduces the cost [17]. Besides, the folding of expressed protein in the periplasm or medium can effectively improve the quality, including stability, solubility, and biological activity of the product [18]. Furthermore, to obtain protein secreted into the periplasm, the outer membrane must be lysed; therefore, protein secretion into the periplasm is less advantageous than protein secretion into the culture medium. Many proteins tend to form inclusion bodies without activity if they cannot be transported out of the cell promptly. Fructan sucrase may be considered such a protein, and facilitating the secretion of fructan might be the best and most efficient way to obtain fructan at a high yield. Extracellular secretion of cytosolic protein into the medium without the requirement of significant cell lysis may be considered an outstanding, efficient, and convenient approach [19]. It has been reported that recombinant maltogenic amylase with codon-optimized versions of native E. coli signal peptides could be effectively transported across inner membranes [20]. Moreover, recombinant $\alpha$-amylase encoded on plasmids was also reported to be expressed extracellularly in E. coli [21]. So far, many raise the E. coli protein secreted extracellular strategies have been reported. So far, a lot of strategies have been reported to improve the secretion of extracellular proteins in Escherichia coli [19]. These studies focused on the application of distinct extracellular secretion pathways [22], optimization of induction conditions [23], co-expression of major exocrine components [24], and structure of leaky strains [25]. Studies have theorized ad shown that some B. subtilis strains possess the fructan sucrase gene and produce the corresponding fructan sucrase. However, little has been known about fructan sucrase until now because the production of fructan sucrase in wild strains is so low that it is difficult to isolate and purify the protein. Therefore, the expression and extracellular secretion of fructan sucrase by genetic engineering was attempted.

In this study, the fructan sucrase was expressed from B. subtilis ZW019 in E. coli by generating different expression constructs with various secretory signal peptides. Meanwhile, the secretion of fructan sucrase was investigated to improve the yield of the enzyme under distinct induction conditions. The recombinant fructan sucrase was purified one step by GEM particles. This study aims to simplify the purification steps and reduce the cost, which provides a possibility for the industrial production of fructan.

\section{Materials and Methods}

\subsection{Bacterial Strains, Culture Conditions, and Plasmids}

B. subtilis ZW019 which was isolated from fermented tofu was used as a source of the fructan sucrase gene in this study. E. coli DH5 $\alpha$ was used for universal gene cloning, and E. coli BL21(DE3) was used for gene expression vectors. All beakers and glass Petri dishes were sterilized at $121^{\circ} \mathrm{C}, 1$ bar per $20 \mathrm{~min}$ [26]. All three strains were grown in 
LB medium ( $1 \%$ tryptone, $0.5 \%$ yeast extract, and $1 \% \mathrm{NaCl})$ at $37^{\circ} \mathrm{C}$, and glycerol stocks were stored at $-80^{\circ} \mathrm{C}$. Lactococcus lactis NZ9000 grown in an M17 medium containing $0.5 \%$ glucose at $30^{\circ} \mathrm{C}$ without shaking was used to prepare GEM particles. The plasmid pET-28a-AcmA-Z maintained in our lab was used as the backbone for the two signals peptide-fructan sucrase fusions.

\subsection{Cloning of the Fructan Sucrase Gene}

Plasmid DNA preparation and deoxyribonucleic acid (DNA) extraction were carried out according to Molecular Cloning [27]. In this study, genomic DNA was extracted using a genomic DNA purification kit. (Tiangen Biotech, Tianjin, China). The coding sequence was amplified by polymerase chain reaction (PCR) using the specific primers shown in Table 1. The amplified PCR fragment was sequenced by GENEWIZ Co., Ltd. (Tianjin, China). The PCR product was purified by agarose gel electrophoresis, digested with restriction enzymes, and inserted into the corresponding sites of the plasmid pET-28a-AcmA-Z to produce the recombinant plasmid pET-28a-AcmA-fructan sucrase-Z. The transformants carrying the desired gene were screened on solid medium containing kanamycin [28]. The inserted gene was detected by PCR and double enzyme (BamHI and PstI) digestion. The full-length fructan sucrase-encoding gene, 1332 bp (GenBank accession no. MT038999), was synthesized by GENEWIZ Co., Ltd. (Tianjin, China). The recombinant expression vector was transformed into E. coli BL21(DE3) for further expression.

Table 1. The sequence of primers.

\begin{tabular}{|c|c|}
\hline Name & Primer Sequence \\
\hline \multicolumn{2}{|r|}{ Primers of cloning of fructan sucrase gene from B. subtilis } \\
\hline BS-F & 5'-CCGCGGATCCAAAGAAACGAACCAAAAG-3' (containing BamHIsite) \\
\hline BS-R & 5'-CCGCCTGCAGTTTGTTAACTGTTAATTG-3' (containing PstIsite) \\
\hline \multicolumn{2}{|c|}{ Primers of cloning of fructan sucrase and secretory signal peptide gene from B. subtilis } \\
\hline BS-FF-F & 5'-CCGCGGATCCAACATCAAAAAGTTTGC-3' (containing BamHIsite) \\
\hline BS-FF-R & 5'-CCGCCTGCAGTTTGTTAACTGTTAATTG-3' (containing PstIsite) \\
\hline \multicolumn{2}{|c|}{ Primers of recombinant expression vectors of fructan sucrase from B. subtilis and signal peptide genes secreted by $E$. coli } \\
\hline BSO-F & $\begin{array}{l}\text { 5'-CGCGGATCCAAAAAAACCGCTATCGCTATCGCTGTTGCTCTGGCTGGTTTCGCTA } \\
\text { CCGTTGCTCAGGCTAAAGAAACGAACCAAAAG-3' (containing BamHIsite) }\end{array}$ \\
\hline BSO-R & 5'-CCGCCTGCAGTTTGTTAACTGTTAATTG-3' (containing PstIsite) \\
\hline
\end{tabular}

\subsection{Determination of Inducement Conditions}

The secretion of fructan sucrase under distinct culture time, temperature, and IPTG concentration was measured, to promote the production of the enzyme. The enzyme was inducted at $37^{\circ} \mathrm{C}, 28{ }^{\circ} \mathrm{C}$, and $18{ }^{\circ} \mathrm{C}$ [29] with $0.5 \mathrm{mM}$ IPTG. The activity of fructan sucrase was tested at $2,4,6,8,12$, and $16 \mathrm{~h}$. The IPTG induction concentrations were set to $0.1,0.2$, $0.5,1.0 \mathrm{mM}$, and the fixed induction temperature was $28^{\circ} \mathrm{C}$. The activity of fructan sucrase was detected only from $0-8 \mathrm{~h}$ and measured every $2 \mathrm{~h}$.

\subsection{Expression and Purification of the Recombinant Enzyme}

E. coli BL21 (DE3) containing gene recombinant expression vector was cultured overnight at $37^{\circ} \mathrm{C}$ in LB medium containing kanamycin $(50 \mu \mathrm{g} / \mathrm{mL})$. Then, the culture solution was diluted $(2 \%)$ to sterilized LB medium $(1 \mathrm{~L})$ containing kanamycin $(50 \mu \mathrm{g} / \mathrm{mL})$, and cultured until the OD600 reached 0.6. Heterologous expression of fructan sucrase was induced by IPTG. The culture was collected by centrifugation at $13,000 \times g$ for $20 \mathrm{~min}$ at $4{ }^{\circ} \mathrm{C}$. The culture supernatant was directly labeled the fraction secreted extracellularly. The sediment was washed with $12 \mathrm{~mL}$ of $50 \mathrm{mM}$ Tris- $\mathrm{HCl}$ (pH 7.2) buffer solution and then ultrasonically disrupted by sonication on ice (2-s pulses with a 4-s rest between pulses, 
$35{ }^{\circ} \mathrm{C}, 45 \%$ power, mode 02 probe $06,20 \mathrm{~min}$ total). After sonication, the solution was centrifuged at $12,800 \times g$ for $17 \mathrm{~min}$; the supernatants were labeled the soluble intracellular fraction, and the cell debris was marked as the insoluble intracellular fraction. The cell debris was resuspended in $10 \mathrm{~mL}$ of $50 \mathrm{mM}$ Tris- $\mathrm{HCl}$ buffer solution. Total enzyme activity was equal to the sum of extracellular and intracellular enzyme activity. Twenty microliters of protein sample were mixed with $20 \mu \mathrm{L}$ of loading buffer and then incubated in a water bath at $100{ }^{\circ} \mathrm{C}$ for $10 \mathrm{~min}$ to denature proteins. Forty microliters of each sample were subjected to sodium dodecyl sulfate-polyacrylamide gel electrophoresis (SDS-PAGE) analysis. SDS-PAGE was performed by $12 \%$ separating gel and $5 \%$ stacking gel on a mini-vertical electrophoresis unit SE 250 (GE Healthcare, PITT, PA, USA). The protein bands were visualized by staining with Coomassie Brilliant Blue R-250 and discolored with distilled water. To facilitate separation and purification, the AcmA tag was assembled to the C-terminus of fructan sucrase as a purification tag [30]. The GEM particles by the L. lactis NZ9000 boiled in $0.1 \mathrm{mM} \mathrm{HCl}$ for $30 \mathrm{~min}$ to obtain, and then washed with PBS. According to boiling grown L. lactis NZ9000 in $0.1 \mathrm{mM} \mathrm{HCl}$ for $30 \mathrm{~min}$, the GEM particles were gained, followed by extensive washing with PBS [31,32]. The GEM method was used to purify the secreted components, which were labeled as "purified secretions". The recombinant fructan sucraseAcmA fusion protein was mixed with the GEM particles for $30 \mathrm{~min}$ [30]. The efficiency of the above purification method was determined by SDS-PAGE electrophoresis.

\subsection{Determination of the Enzyme Activity}

The activity of fructan sucrase was estimated by testing the release of reducing sugar in a solution $(2 \mathrm{~mL})$, which contains $10 \%$ sucrose solution, fructan sucrase, and $200 \mathrm{mM}$ sodium phosphate buffer (pH 5.6), after incubation in a $50{ }^{\circ} \mathrm{C}$ water bath for $30 \mathrm{~min}$. One milliliter of 3,5-dinitrosalicylic acid (DNS) solution was added to the reaction mixture to quench the reaction, and then the mixture was cultured in boiling water for $10 \mathrm{~min}$ or until the color was observed. After the solution was cooled to room temperature, the light absorption value was detected at $540 \mathrm{~nm}$. One unit of fructan sucrase activity was defined as the amount of enzyme needed to release $1 \mu \mathrm{mol}$ of reducing sugar per minute under the assay conditions [19].

\subsection{Effect of $p H$, Temperature, and Ions on the Activity of the BSO Recombinant Fructan Sucrase}

Under the most suitable conditions, the secretion of protein expressed from the recombinant expression vector in E. coli was almost the same as that in B. subtilis, so the BSO recombinant expression vectors were selected to study the properties of secreted fructan sucrase. The effect of $\mathrm{pH}$ on the activity of fructan sucrase was determined by changing the $\mathrm{pH}$ of the substrate between 4.0 and 6.6. In a $50 \mathrm{mM}$ Tris- $\mathrm{HCl}(\mathrm{pH}$ 7.2) buffer solution, the enzyme activity was measured at different reaction temperatures from $25^{\circ} \mathrm{C}$ to $65^{\circ} \mathrm{C}$ (tested at $5{ }^{\circ} \mathrm{C}$ intervals), and the effect of temperature on the BSO fructan sucrase activity was analyzed. To determine the effect of different ions on the activity of the BSO recombinant fructan sucrase, $\mathrm{K}^{+}, \mathrm{Mg}^{2+}, \mathrm{Ca}^{2+}, \mathrm{Fe}^{2+}, \mathrm{Ba}^{2+}, \mathrm{Ni}^{2+}, \mathrm{Mn}^{2+}$, and $\mathrm{Zn}^{2+}$ were added to the reaction, and other variables were controlled to be consistent. The concentration of metal ions was $5 \mathrm{mM}$ and $50 \mathrm{mM}$, respectively.

\subsection{Determining the Kinetic Parameters of BSO Recombinant Fructan Sucrase}

The kinetic parameters were determined at $50{ }^{\circ} \mathrm{C}$ with sucrose concentrations ranging from 15.6 to $200 \mathrm{mM}$ (sodium acetate-acetate buffer, $\mathrm{pH}=5.6$ ). A plot was constructed with the inverse of the substrate concentration and the inverse of the reaction rate, and a linear fit of the plot was used to obtain the value of the Michaelis-Menten constant Km.

\subsection{Data Analysis}

All measurements and assays were performed more than three times, and the data were analyzed and the figures were produced by GraphPad Prism 5.0 (GraphPad Software, San Diego, CA, USA). The values are presented as the means \pm standard deviations. A 
$p$-value $<0.01$ indicated significant differences in the analysis of multiple comparison tests and variance (ANOVA).

\section{Results and Discussion}

\subsection{Cloning of the Fructan Sucrase Gene}

The gene encoding fructan sucrase from $B$. subtilis was cloned with the native signal sequence, named BS-FF, or without the native signal sequence, named BS, and expressed in E. coli BL21. Clones containing the secretory signal peptide of $E$. coli fused with the fructan sucrase gene of $B$. subtilis were named BSO. To avoid false-positive clones, the commonly used primers AcmA-Term and T7 were used to identify positive clones by PCR. Lots of exogenous proteins have been expressed in E. coli successfully [33].

\subsection{Effect of Temperature, Time, IPTG Concentration on Induced Expression}

\subsubsection{Effect of Temperature on Induction Expression}

The effect of the cultivation temperature on the expression of BSO and BS-FF, which contain secretion signal peptides, was detected at three different temperatures $(18,28$, and $37^{\circ} \mathrm{C}$ ). As shown in Figure $1 \mathrm{~A}$, at $18^{\circ} \mathrm{C}$ or $37^{\circ} \mathrm{C}$, the extracellular activity of fructan sucrase was very low because the temperature had a strong influence on the metabolic rate of E. coli. At $18{ }^{\circ} \mathrm{C}$, the expression level of the foreign gene was insufficient; at $37^{\circ} \mathrm{C}$ the expressed fructan sucrase could not be transported out of the cell on time, and inactive inclusion bodies were formed in the cell, so secretory expression was low at this temperature. However, at a culture temperature of $28^{\circ} \mathrm{C}$, recombinant fructan sucrase was induced with $0.5 \mathrm{mM}$ IPTG, and the recombinant enzymes were successfully produced in high amounts. However, the BS clones, which contained no signal peptide, did not exhibit secretory expression (Figure 1A).

\subsubsection{Effect of Time on Induced Expression}

The secreted expression of IPTG-induced fructan sucrase in E. coli gradually increased over time and showed a downward trend after the highest enzyme activity was reached; the enzyme activity reached the highest value $8 \mathrm{~h}$ after IPTG was added (Figure 1A).

\subsubsection{Effect of IPTG Concentration on Induced Expression}

As depicted in Figure 1B, the optimal IPTG concentration to induce the expression of the BSO recombinant enzyme was approximately $1.0 \mathrm{mM}$, and the optimal IPTG concentration to induce the expression of the BS-FF recombinant enzyme was approximately $0.5 \mathrm{mM}$. Enzyme expressed from the BS recombinant expression vector was still not secreted at either IPTG concentration.

The BS-FF clones with the secretory signal peptide of B. subtilis secreted $95.25 \%$ of the total fructan sucrase outside the cell, while the BSO clones with the secretory signal peptide of E. coli secreted $98.78 \%$ of the fructan sucrase outside the cell. BS cells expressing fructan sucrose without a secreted signaling peptide secreted $6.48 \%$ of the total fructan sucrase. The small amount of extracellular activity detected might be due to the lysis of a few host cells. The intracellular fructan sucrase activity of the intracellular soluble fraction of BS cells was $66.78 \%$. No enzyme activity was detected in the insoluble intracellular fraction of BS cells. However, as shown in Figure 2, the target protein was present in the insoluble part of the cell. The extracellular enzyme activity of BS was very low because BS does not contain secreted signal peptides, intracellular fructans sucrase cannot be transferred to the extracellular space and intracellular inclusion bodies were formed [34,35]. It is well known that inclusion body formation limits protein overexpression in E. coli [36]. The inclusion bodies were pellets that lacked both an advanced structure and biological activity. By reducing the induction temperature and IPTG concentration, the formation of inclusion bodies could be avoided as much as possible [37]. Only exceedingly low fructan sucrase activity $(0.1 \mathrm{U} / \mathrm{mL})$ was determined in the culture medium when the expression of fructan sucrase was induced with $0.5 \mathrm{mM}$ IPTG at 18 or $37^{\circ} \mathrm{C}$, and this result was similar to 
previous reports $[38,39]$. In contrast, the activity of the expressed recombinant enzyme was highest at the optimal induction temperature of $28^{\circ} \mathrm{C}$.

BS

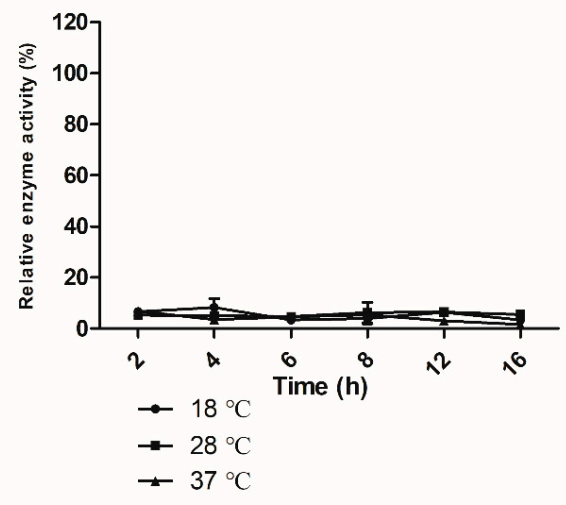

BSO

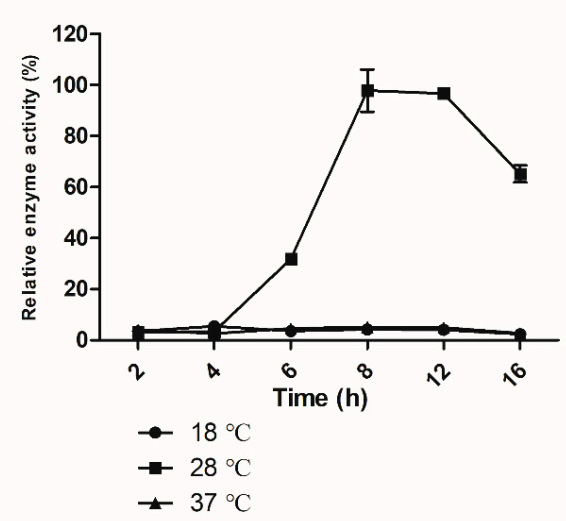

BS-FF

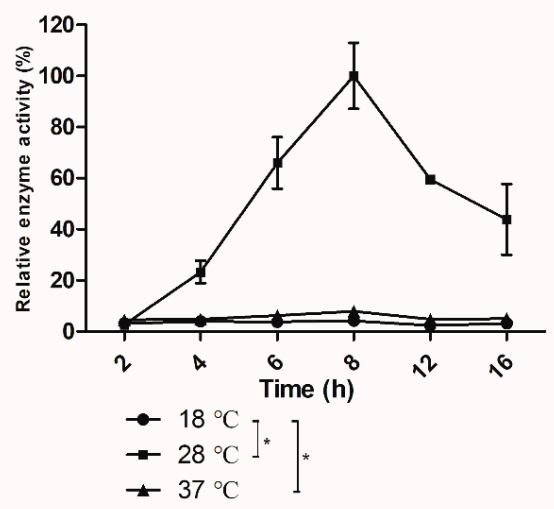

(A)
BS

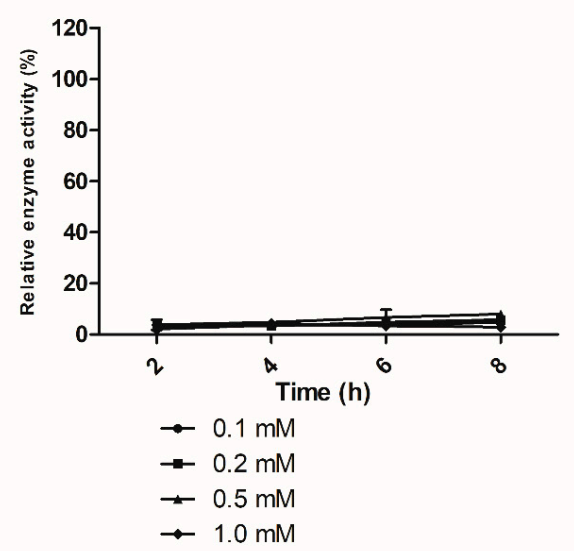

BSO

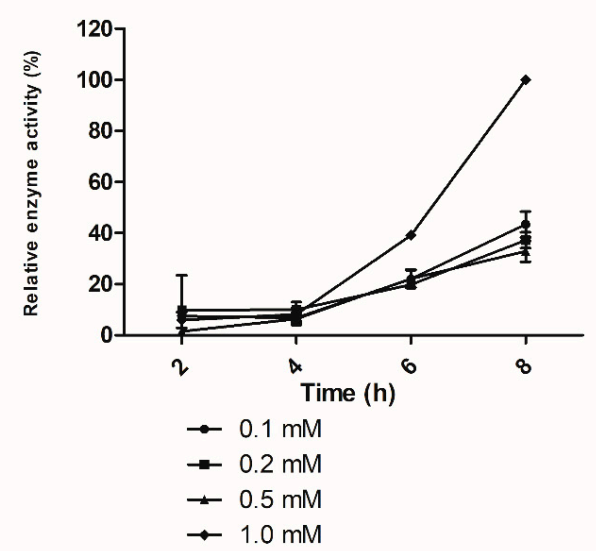

BS-FF

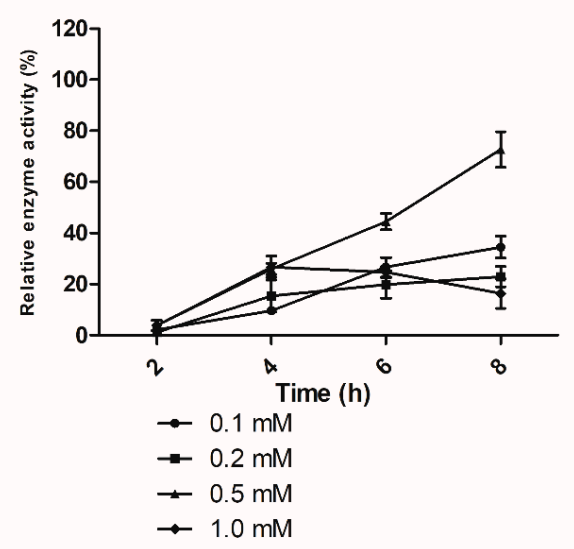

(B)

Figure 1. Effect of temperature, time, and IPTG concentration on the expression of BS, BSO, and BS-FF. (A) Effect of temperature and time on the expression of BS, BSO, and BS-FF. The expression of recombinant vectors in $E$. coli was induced by $0.5 \mathrm{mM}$ IPTG, and cultures were incubated at different temperatures and times. (B) Effect of IPTG concentration on the expression of BS, BSO, and BS-FF. The expression of recombinant vectors in E. coli was induced by different concentrations of the inducer IPTG, and cultures were incubated at the optimal temperature of $28{ }^{\circ} \mathrm{C}$ for $8 \mathrm{~h}$. The values are representative results obtained from at least three experiments. Error bars indicate standard deviations (SD) based on more than three independent experiments. ${ }^{*} p<0.01, t$-test. 
(A)

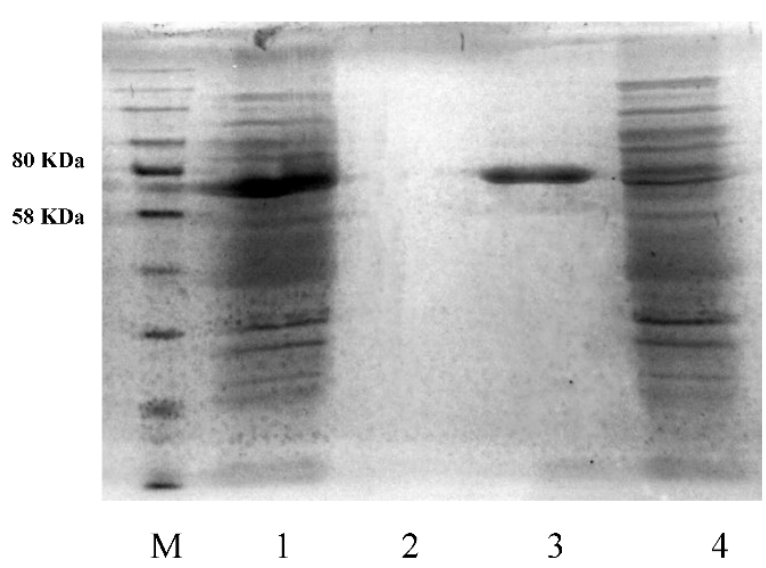

(B)

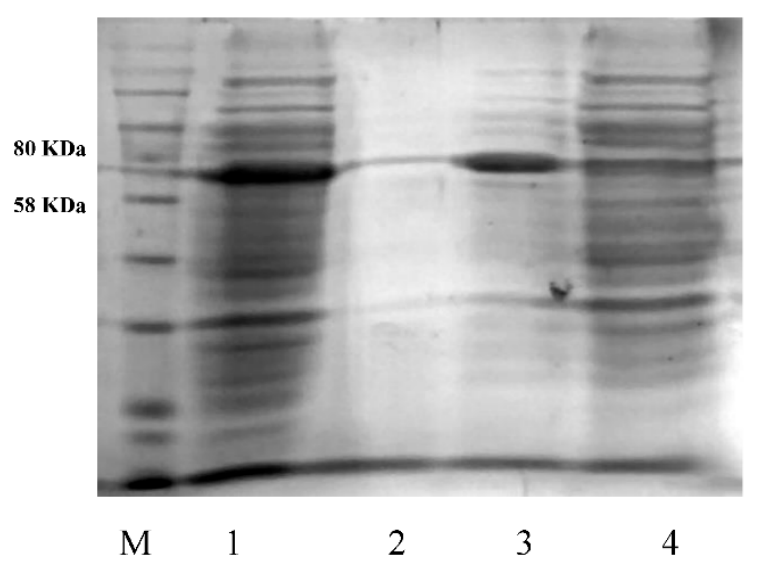

Figure 2. SDS-PAGE gels stained with Coomassie Brilliant Blue. (A) The fructan sucrase secreted by BSO was purified by GEM. Lanes: M, molecular mass standards; (1) extracellular fraction of cells producing recombinant fructan sucrase with an E. coli signal peptide; (2) purified extracellular recombinant fructan sucrase produced with a signal peptide; (3) GEM particles; (4) intracellular fraction of cells producing recombinant fructan sucrase with an E. coli signal peptide. The arrow indicates recombinant fructan sucrase. (B) The fructan sucrase secreted by BS-FF was purified by GEM. Lanes: M, molecular mass standards; (1) extracellular fraction of cells producing recombinant fructan sucrase with a B. subtilis signal peptide; (2) fructan sucrase purified from extracellular fraction. The arrow indicates recombinant fructan sucrase; (3) GEM particles; (4) intracellular fraction of cells producing recombinant fructan sucrase with a B. subtilis signal peptide. The arrow indicates fructan sucrase.

\subsection{Expression and Purification of Recombinant Fructan Sucrase}

The secretion expression of BSO was induced at $28{ }^{\circ} \mathrm{C}$ with $1.0 \mathrm{mM}$ IPTG. BS-FF expression was induced at $28^{\circ} \mathrm{C}$ with $0.5 \mathrm{mM}$ IPTG. The cells were cultured for $8 \mathrm{~h}$ after induction to maximize extracellular secretion. The supernatant was collected, centrifuged at $4{ }^{\circ} \mathrm{C}, 12,000 \times g$ for $30 \mathrm{~min}$, and the protein distribution was detected. SDS-PAGE analysis showed that a distinct protein band appeared (approximately $58 \mathrm{kDa}$ ) (Figure 2). A DNS assay was performed; the amount of fructan sucrase secreted to the outside of the cell reached $95.25 \%$ for the clones with the secretory signal peptide of B. subtilis, while for the clones with the signal peptide sequence of $E$. coli, the amount of fructan sucrase secreted to the outside of the cell reached $98.78 \%$. GEM particles were mixed with the supernatant after centrifugation at room temperature for more than $30 \mathrm{~min}$. The supernatant after centrifugation was mixed with GEM particles at room temperature for more than $30 \mathrm{~min}$ to achieve the purification of the enzyme. As shown in Figure 2, GEM particles did not contain any protein, so no impurities were introduced during the purification process. GEM particles could bind to the AcmA tag with most of the extracellular target protein, and the target bands were thicker and more visible. At the same time, there were no bands other than the target bands (Figure 2), indicating that the purification with GEM particles was sufficient. In this experiment, the GEM purification method we choose saves the purification time and reduces the purification steps compared with the traditional $\mathrm{Ni}$ column purification method [40]. The traditional Ni column purification method requires the use of a large amount of imidazole to elute the enzyme from the Ni column [41]. However, the GEM particles used in this study did not need any strong chemical reagents in the purification process. On the other hand, the soluble fraction of the cell was analyzed by SDS-PAGE. As shown in Figure 2, the soluble fraction did not contain the target band, indicating that the cells did not contain fructan sucrase. There were many nontarget bands in the intracellular soluble components, indicating that there were many nontarget proteins in the intracellular components, which made it difficult to isolate and purify 
fructan sucrase. The signal peptides from B. subtilis and E. coli share common features. The secretion efficiency of these microbes depends not only on the signal peptide but also on the sequence of the mature protein, especially the sequence at the N-terminus [42]. The E. coli expression system has been studied more than the B. subtilis secretion system. Subtilisin, mannanase, chitinase, $\alpha$-amylase, and xylanase have been expressed in $E$. coli. It seems possible that signal peptides from Bacillus species could be applied for the extracellular secretion of other recombinant proteins produced by the E. coli system. Similarly, the secretory signal peptide of $E$. coli is also very suitable for secreting the fructan sucrase gene of B. subtilis.

\subsection{Effect of $p H$, Temperature, and Ions on the Activity of Recombinant Fructan Sucrase \\ 3.4.1. Effect of $\mathrm{pH}$ on the Activity of Fructan Sucrase}

Under the optimal induction conditions, the secreting effect of the clone with the signal peptide gene sequence of $E$. coli was almost the same as that of the clone with the signal peptide gene sequence of $B$. subtilis, so the $\mathrm{BSO}$ recombinant expression vectors were selected to study the properties of secreted fructan sucrase. As shown in Figure 3A, maximal activity was achieved at $\mathrm{pH}$ 5.6. From $\mathrm{pH}$ 4.0-5.6, the activity of fructan sucrase increased with the increase in $\mathrm{pH}$, and the highest value was observed at $\mathrm{pH}$ 5.6. When the $\mathrm{pH}$ was lower than 4.6 , the activity of fructan sucrase was low ( $<50 \%$ of the maximum). The fructan sucrase of B. subtilis ZW019 was adapted to the slightly acidic $\mathrm{pH}$, which was similar to the conclusion of a fructan sucrase produced by other strains [43].

\subsubsection{Effect of Temperature on the Activity of Fructan Sucrase}

As shown in Figure $3 \mathrm{~B}$, from $25-50{ }^{\circ} \mathrm{C}$, fructan sucrase activity increased with increasing temperature, while activity decreased sharply when the temperature was increased from $50-65{ }^{\circ} \mathrm{C}$. The optimum temperature was $50{ }^{\circ} \mathrm{C}$, and the enzyme activity was almost completely lost at $65^{\circ} \mathrm{C}$, indicating that fructan sucrase was not resistant to high temperatures and was sensitive to heat.

\subsubsection{Effect of Ions on the Activity of Recombinant Fructan Sucrase}

Generally, metal ions have a great influence on protein folding and catalytic processes [44]. As shown in Figure 3C, the following metal ions only slightly inhibited enzyme activity at low concentrations: $\mathrm{K}^{+}, \mathrm{Zn}^{2+}$, and $\mathrm{Ni}^{2+}$. On the other hand, $\mathrm{Ca}^{2+}, \mathrm{Mg}^{2+}$, and $\mathrm{Mn}^{2+}$ strongly promoted fructan sucrase activity, especially $\mathrm{Mn}^{2+}$, which increased the fructan sucrase activity by approximately $143 \%$. $\mathrm{Ba}^{2+}$ and $\mathrm{K}^{+}$at low concentrations had little influence on the activity of fructan sucrase. At higher concentrations, $\mathrm{Mg}^{2+}, \mathrm{Zn}^{2+}$, $\mathrm{Ni}^{2+}$, and $\mathrm{Mn}^{2+}$ significantly inhibited the enzyme activity, $\mathrm{Fe}^{2+}, \mathrm{Ba}^{2+}$, and $\mathrm{K}^{+}$slightly inhibited the activity of fructan sucrase, and $\mathrm{Ca}^{2+}$ promoted the enzyme activity. The divalent metal cations play a key role in the extracellular expression of recombinant protein in E. coli $[23,45]$.

\subsection{The Kinetic Parameters of Recombinant Fructan Sucrase}

The Km and Vmax values were detected by nonlinear fit analysis based on EadieHofstee plots [46]. As shown in Figure 4, the initial reaction rate was determined with a sucrose concentration of 15.6-200 mM. Recombinant fructan sucrase hydrolyzed sucrose at $50{ }^{\circ} \mathrm{C}$, the Michaelis-Menten constant $(\mathrm{Km})$ was $33.96 \mathrm{~g} / \mathrm{L}$, and the maximum reaction rate (Vmax) was $0.63 \mathrm{~g} /(\mathrm{L} \cdot \mathrm{min})$. According to a recently published review of fructan sucrase $[47,48]$, it still suggests that fructan sucrase in this study has a special catalytic ability to transform sucrose as a substrate. 


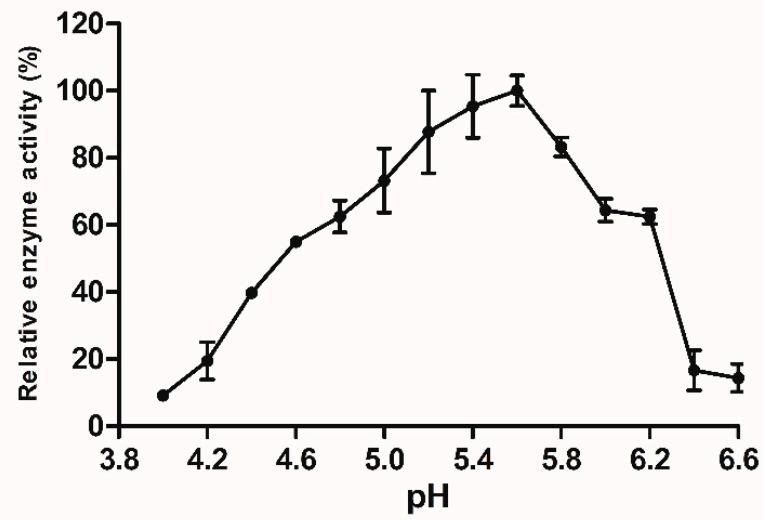

(A)

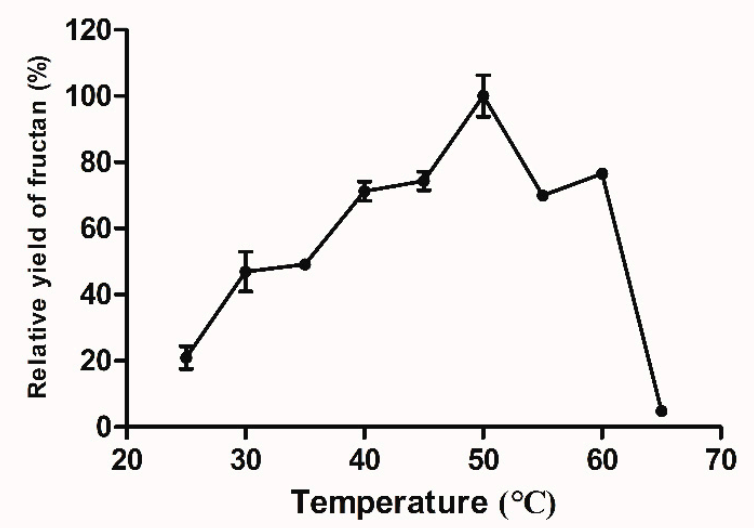

(B)

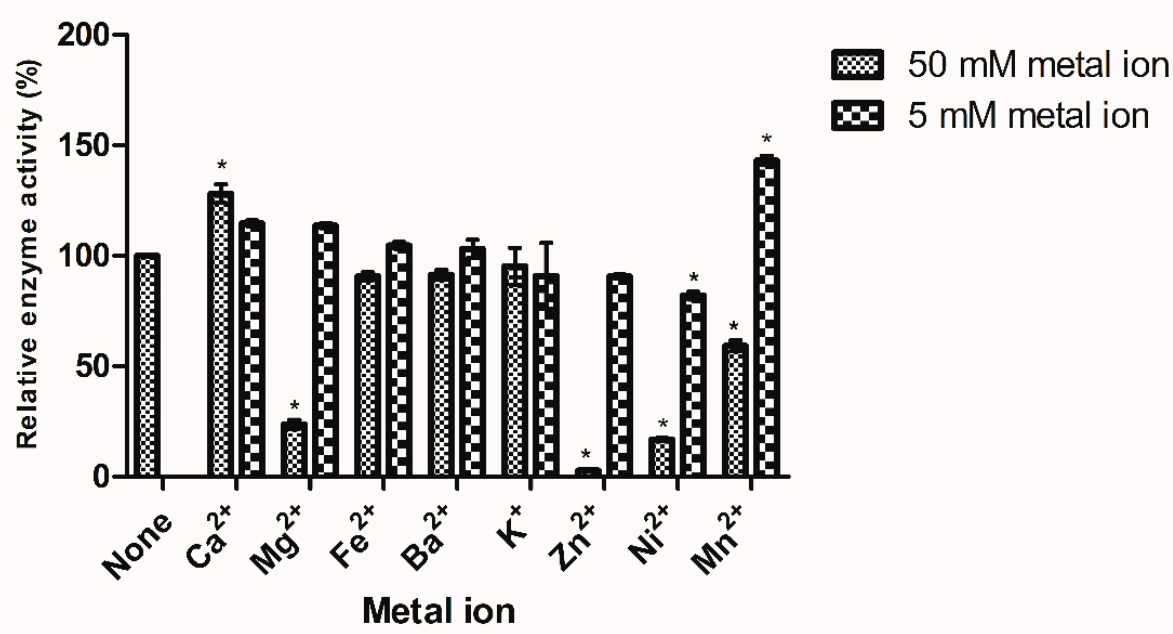

(C)

Figure 3. Effect of $\mathrm{pH}$, temperature, metal ions on the activity of recombinant fructan sucrase. (A) Effect of $\mathrm{pH}$ on the activity of recombinant fructan sucrase; (B) effect of temperature on the activity of recombinant fructan sucrase; (C) effect of metal ions on the activity of recombinant fructan sucrase. The values are representative results obtained from at least three experiments. Error bars indicate standard deviations (SD) based on more than three independent experiments. ${ }^{*} p<0.01, t$-test. 


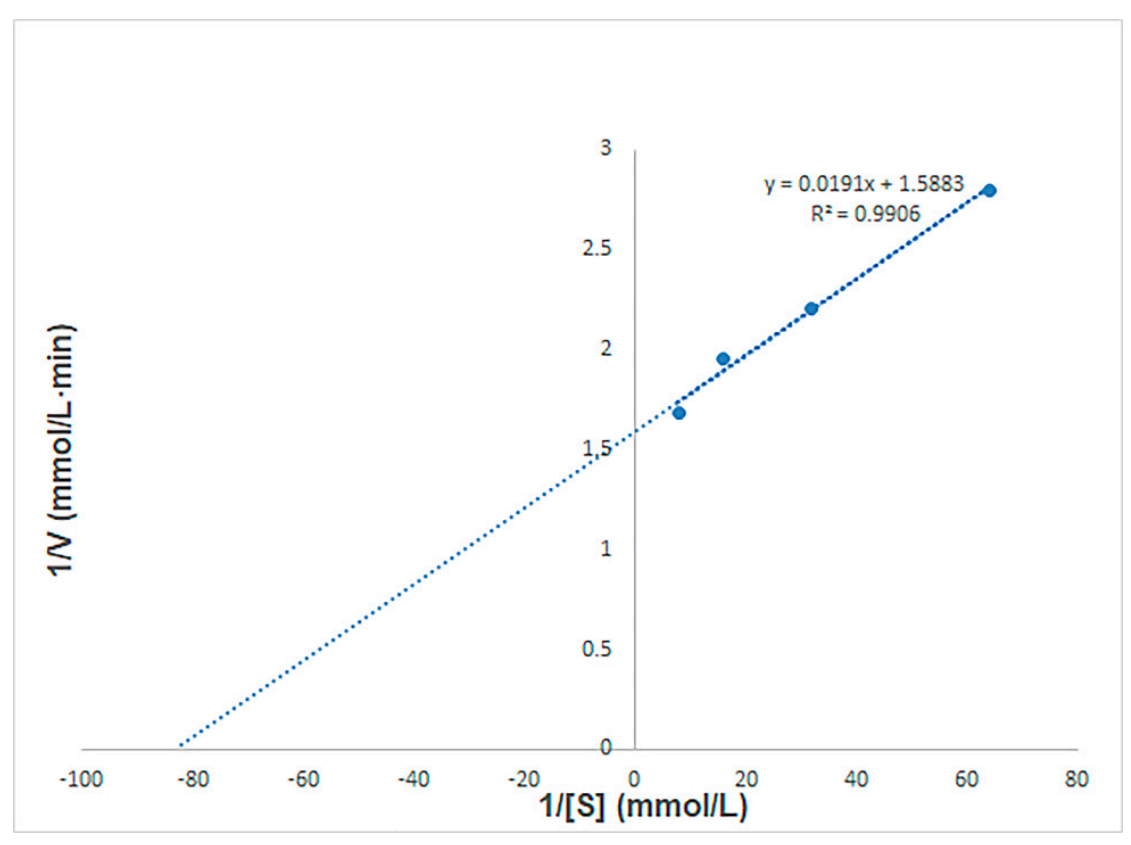

Figure 4. Michaelis-Menten kinetic parameters.

\section{Conclusions}

In the study, a difficult to isolate and purity fructan sucrase produced wild B. subtilis strain was firstly expressed extracellularly in E. coli. Signal peptides suitable for the secretion of fructan sucrase in E. coli were found. The signal peptides from E. coli and B. subtilis both enabled the secretion of recombinant proteins into the extracellular environment. Extracellular fructan sucrase was purified and immobilized by GEM particles in one step. The effect of $\mathrm{pH}$, temperature, and ions on the activity of recombinant fructan sucrase were determined. The work presented herein illustrates a useful method to easily and efficiently get fructan sucrase, which will provide a basis for the enzymology of bacillus fructan sucrase and its industrial application.

Author Contributions: J.W., conceptualization, methodology, investigation, and writing-original draft; H.X., data curation, investigation, formal analysis, and writing-review and editing. F.Z., investigation, writing-review and editing, and formal analysis; B.Z., software, validation, and supervision; M.X., validation, supervision, and software; Z.Z., supervision and software; Y.H., project administration, resources, supervision, and funding acquisition. All authors have read and agreed to the published version of the manuscript.

Funding: This research was funded by the Key Technology R \& B Program of Tianjin, China, grant number 19YFZCSN00100.

Institutional Review Board Statement: Not applicable.

Informed Consent Statement: Not applicable.

Data Availability Statement: Data is in agreement with the MDPI Research Data Policies. Most of the data are available in this manuscript. More specific data can be requested from the corresponding author.

Acknowledgments: This work was financially supported by the Key Technology R \& B Program of Tianjin, China (19YFZCSN00100).

Conflicts of Interest: The authors declare no conflict of interest. The funders had no role in the design of the study; in the collection, analyses, or interpretation of data; in the writing of the manuscript, or in the decision to publish the results. 


\section{References}

1. Belghith, K.S.; Dahech, I.; Hamden, K.; Feki, A.; Mejdoub, H.; Belghith, H. Hypolipidemic effect of diet supplementation with bacterial levan in cholesterol-fed rats. Int. J. Biol. Macromol. 2012, 50, 1070-1074. [CrossRef]

2. Byun, B.Y.; Lee, S.J.; Mah, J.H. Antipathogenic activity and preservative effect of levan ( $\beta-2,6$-fructan), a multifunctional polysaccharide. Int. J. Food Sci. Technol. 2014, 49, 238-245. [CrossRef]

3. Dahech, I.; Harrabi, B.; Hamden, K.; Feki, A.; Mejdoub, H.; Belghith, H.; Belghith, K.S. Antioxidant effect of nondigestible levan and its impact on cardiovascular disease and atherosclerosis. Int. J. Biol. Macromol. 2013, 58, 281-286. [CrossRef]

4. Srikanth, R.; Siddartha, G.; Reddy, C.H.; Harish, B.S.; Ramaiah, M.J.; Uppuluri, K.B. Antioxidant and anti-inflammatory levan produced from Acetobacter xylinum NCIM2526 and its statistical optimization. Carbohydr. Polym. 2015, 123, 8-16. [CrossRef] [PubMed]

5. Methus, K.; Rath, P.; Thanapon, C.; Karan, W.; Surasak, C. Computational design of oligosaccharide producing levansucrase from Bacillus licheniformis RN-01 to improve its thermostability for production of levan-type fructooligosaccharides from sucrose. Int. J. Biol. Macromol. 2020, 160, 252-263. [CrossRef]

6. Srikanth, R.; Reddy, C.H.; Siddartha, G.; Ramaiah, M.J.; Uppuluri, K.B. Uppuluri review on production, characterization and applications of microbial levan. Carbohydr. Polym. 2015, 120, 102-114. [CrossRef] [PubMed]

7. Ragab, T.I.M.; Shalaby, A.S.G.; Awdan, S.A.E.; El-Bassyouni, G.T.; Salama, B.M.; Helmy, W.A.; Esawy, M.A. Role of levan extracted from bacterial honey isolates in curing peptic ulcer: In vivo. Int. J. Biol. Macromol 2020, 142, 64-573. [CrossRef] [PubMed]

8. Raveendran, S.; Parameswaran, B.; Ummalyma, S.B.; Abraham, A.; Mathew, A.K.; Madhavan, A.; Rebello, S.A. Pandey Applications of microbial enzymes in food industry. Food Technol. Biotechnol. 2018, 56, 16-30. [CrossRef] [PubMed]

9. Lalitagauri, R.; Sunita, P.; Debabrata, B. Enzymes-An existing and promising tool of food processing industry. Recent Pat. Biotechnol. 2016, 10, 58-71. [CrossRef]

10. Trujilloa, L.E.; Arrietaa, J.G.; Dafhnisa, F.; Garcíab, J.; Valdésb, J.; Tambarac, Y.; Pérezb, M.; Hernándeza, L. Fructo-oligosaccharides production by the Gluconacetobacter diazotrophicus levansucrase expressed in the methylotrophic yeast Pichia pastoris. Enzym. Microb Technol. 2001, 28, 139-144. [CrossRef]

11. Gao, S.; Qi, X.; Hart, D.J.; Gao, H.; An, Y. Expression and characterization of levansucrase from Clostridium acetobutylicum. J. Agric. Food Chem. 2017, 65, 867-871. [CrossRef] [PubMed]

12. Ni, D.; Xu, W.; Bai, Y.; Zhang, W.; Zhang, T.; Mu, W. Biosynthesis of levan from sucrose using a thermostable levansucrase from Lactobacillus reuteri LTH5448. Int. J. Biol. Macromol. 2018, 113, 29-37. [CrossRef] [PubMed]

13. Xavier, J.R.; Ramana, K.V. Optimization of levan production by cold-active Bacillus licheniformis ANT 179 and fructooligosaccharide synthesis by its levansucrase. Appl. Biochem. Biotechnol. 2017, 181, 986-1006. [CrossRef] [PubMed]

14. Iliev, I.; Vasileva, T.; Bivolarski, V.; Salim, A.; Morel, S.; Rabier, P.; Gabriel, V. Optimization of the expression of levansucrase L17 in recombinant E. coli. Biotechnol. Biotechnol. Equip. 2018, 32, 477-486. [CrossRef]

15. Ishida, R.; Sakaguchi, K.; Matsuzaki, C.; Katoh, T.; Ishida, N.; Yamamoto, K.; Hisa, K. Levansucrase from Leuconostoc mesenteroides NTM048 produces a levan exopolysaccharide with immunomodulating activity. Biotechnol. Lett. 2016, 38, 681-687. [CrossRef]

16. Liu, Q.; Yu, S.H.; Zhang, T.; Jing, B.; Mu, W.M. Efficient biosynthesis of levan from sucrose by a novel levansucrase from Brenneria goodwinii. Carbohydr. Polym. 2017, 157, 1732-1740. [CrossRef]

17. Jong, W.S.; Saurí, A.; Luirink, J. Extracellular production of recombinant proteins using bacterial autotransporters. Curr. Opin. Biotechnol. 2010, 21, 646-652. [CrossRef]

18. Choi, J.H.; Lee, S.Y. Secretory and extracellular production of recombinant proteins using Escherichia coli. Appl. Microbiol. Biotechnol. 2004, 64, 625-635. [CrossRef]

19. Su, L.; Xu, C.; Woodard, R.W.; Chen, J.; Wu, J. A novel strategy for enhancing extracellular secretion of recombinant proteins in Escherichia coli. Appl. Microbiol. Biotechnol. 2013, 97, 6705-6713. [CrossRef]

20. Sambasivam, G.; Nair, S.; Karthikeyan, G. Effect of codon-optimized E-coli signal peptides on recombinant Bacillus stearothermophilus maltogenic amylase periplasmic localization, yield and activity. J. Ind. Microbiol. Biotechnol. 2014, 41, 1435-1442. [CrossRef]

21. Chen, J.; Gai, Y.; Fu, G.; Zhou, W.; Zhang, D.; Wen, J. Enhanced extracellular production of $\alpha$-amylase in Bacillus subtilisby optimization of regulatory elements and over-expression of PrsA lipoprotein. Biotechnol. Lett. 2015, 37, 899-906. [CrossRef] [PubMed]

22. Angkawidjaja, C.; Kuwahara, K.; Omori, K.; Koga, Y.; Takano, K.; Kanaya, S. Extracellular secretion of Escherichia coli alkaline phosphatase with a C-terminal tag by type I secretion system: Purification and biochemical characterization. Protein. Eng. Des. Sel. 2006, 19, 337-343. [CrossRef] [PubMed]

23. Li, Z.F.; Li, B.; Liu, Z.G.; Wang, M.; Gu, Z.B.; Du, G.C.; Wu, J.; Chen, J. Calcium leads to further increase in glycine-enhanced extracellular secretion of recombinant alpha-cyclodextrin glycosyltransferase in Escherichia coli. J. Agric. Food Chem. 2009, 57, 6231-6237. [CrossRef] [PubMed]

24. Matos, C.F.R.O.; Branston, S.D.; Albiniak, A.; Dhanoya, A.; Robinson, C. High-yield export of a native heterologous protein to the periplasm by the Tat translocation pathway in Escherichia coli. Biotechnol. Bioeng. 2012, 109, 2533-2542. [CrossRef] [PubMed]

25. Kujau, M.J.; Hoischen, C.; Riesenberg, D.; Gumpert, J. Expression and secretion of functional miniantibodies McPC603scFvDhlx in cell-wall-less L-form strains of Proteus mirabilisand Escherichia coli: A comparison of the synthesis capacities of $L$-form strains with an E. coli producer strain. Appl. Microbiol. Biotechnol. 1998, 49, 51-58. [CrossRef] 
26. Lech, M. Optimisation of protein-free waste whey supplementation used for the industrial microbiological production of lactic acid. Biochem. Eng. J. 2020, 157, 107531. [CrossRef]

27. Wood, E.J. Molecular cloning, a laboratory manual. Biochem. Educ. 1983, 11, 182-183. [CrossRef]

28. Liu, S.L.; Du, K.; Chen, W.Z.; Liu, G.; Xing, M. Effective approach to greatly enhancing selective secretion and expression of three cytoplasmic enzymes in Escherichia coli through synergistic effect of EDTA and lysozyme. J. Ind. Microbiol. Biotechnol. 2012, 39, 1301-1307. [CrossRef]

29. Guo, Y.; Bian, W.; Zhang, Y. Expression in Escherichia coli, purification and characterization of LRSAM1, a LRR and RING domain E3 ubiquitin ligase. Protein Expres Purif. 2017, 129, 158-161. [CrossRef]

30. Zhao, F.K.; Song, Q.Z.; Wang, B.B.; Du, R.P.; Han, Y.; Zhou, Z.J. Secretion of the recombination $\alpha$-amylase in Escherichia coli and purification by the gram-positive enhancer matrix (GEM) particles. Int. J. Biol. Macromol. 2019, 123, 91-96. [CrossRef]

31. Li, P.C.; Qiao, X.W.; Zheng, Q.S.; Hou, J.B. Immunogenicity and immunoprotection of porcine circovirus type 2 (PCV2) Cap protein displayed by Lactococcus lactis. Vaccine 2016, 34, 696-702. [CrossRef] [PubMed]

32. Saluja, V.; Visser, M.R.; Veer, W.T.; Roosmalen, M.L.V.; Leenhouts, K.; Hinrichs, W.L.J.; Huckriede, A.; Frijlink, H.W. Influenza antigen-sparing by immune stimulation with Gram-positive enhancer matrix (GEM) particles. Vaccine 2010, 28, 7963-7969. [CrossRef] [PubMed]

33. Wang, P.L.; Qin, W.T.; Xu, J.T.; Yan, Y.R.; Tian, J.; Wu, N.F.; Yao, B. Enhancing the soluble expression of an amylase in Escherichia coli by the mutations related to its domain interactions. Protein Expr. Purif. 2016, 120, 35-41. [CrossRef] [PubMed]

34. Sumitomo, N.; Ozaki, K.; Kawai, S.; Ito, S. Nucleotide sequence of the gene for an alkaline endoglucanase from an Alkalophilic Bacillus and its expression in Escherichia coli and Bacillus subtilis. Biosci. Biotechnol. Biochem. 1992, 6, 872-877. [CrossRef]

35. Solingen, P.; Meijer, D.; Kleij, W.A.; Barnett, C.; Bolle, R.; Power, S.D.; Jones, B.E. Cloning and expression of an endocellulase gene from a novel Streptomycete isolated from an East African soda lake. Extremophiles 2001, 5, 333-341. [CrossRef] [PubMed]

36. Srensen, H.P.; Mortensen, K.K. Advanced genetic strategies for recombinant protein expression in Escherichia coli. J. Biotechnol. 2005, 115, 113-128. [CrossRef]

37. Meng, F.Q.; Zhao, H.Z.; Zhang, C.; Lu, F.X.; Bie, X.M. Expression of a novel bacteriocin-The plantaricin Pln1-In Escherichia coli and its functional analysis. Protein Expr. Purif. 2016, 119, 85-93. [CrossRef]

38. Laymon, R.A.; Adney, W.S.; Mohagheghi, A.; Himmel, M.E.; Thomas, S.R. Cloning and expression of full-length Trichoderma reesi cellobiohydrolase I cDNAs in Escherichia coli. Appl. Biochem. Biotechnol. 1996, 57-58, 389-397. [CrossRef]

39. Tang, B.; Pan, H.; Zhang, Q.; Ding, L. Cloning and expression of cellulase gene EG1 from Rhizopus stolonifer var. reflexus TP-02 in Escherichia coli. Bioresour. Technol. 2009, 100, 6129-6132. [CrossRef]

40. Zhao, B.; Du, R.; Wang, J.Y.; Xu, M.; Han, Y.; Zhou, Z.J. Purification and biochemical characterization of a novel glucansucrase from Leuconostoc citreum B-2. Biotechnol. Lett. 2020, 42, 1535-1545. [CrossRef]

41. Liu, Y.; Huang, L.; Guo, W.; Jia, L.B.; Fu, Y.; Gui, S.; Lu, F.P. Cloning, expression, and characterization of a thermostable and $\mathrm{pH}$-stable laccase from Klebsiella pneumoniae and its application to dye decolorization. Process Biochem. 2016, 53, 125-134. [CrossRef]

42. Malik, B.; Rashid, N.; Ahmad, N.; Akhtar, M. Escherichia coli signal peptidase recognizes and cleaves the signal sequence of $\alpha$-amylase originating from Bacillus licheniformis. Biochemistry (Moscow) 2013, 78, 958-962. [CrossRef] [PubMed]

43. Hövels, M.; Kosciow, K.; Kniewel, J.; Jakob, F.; Deppenmeier, U. High yield production of levan-type fructans by Gluconobacter japonicus LMG 1417. Int. J. Biol. Macromol. 2020, 164, 295-303. [CrossRef] [PubMed]

44. Oliveira, A.N.D.; Oliveira, L.A.D.; Andrade, J.S. Partial characterization of amylases of two Indigenous Central Amazonian Rhizobia Strains. Braz. Arch. Biol. Techn. 2010, 53, 35-45. [CrossRef]

45. Ding, R.; Li, Z.; Chen, S.; Wu, D.; Wu, J.; Chen, J. Enhanced secretion of recombinant $\alpha$-cyclodextrin glucosyltransferase from $E$. coli by medium additives. Process. Biochem. 2010, 45, 880-886. [CrossRef]

46. Fuhrmann, G.F.; Völker, B. Misuse of graphical analysis in nonlinear sugar transport kinetics by Eadie-Hofstee plots. Biochim. Biophys. Acta 1993, 1145, 180-182. [CrossRef]

47. Xu, W.; Ni, D.; Zhang, W.; Guang, C.; Zhang, T.; Mu, W. Recent advances in Levansucrase and Inulosucrase: Evolution, characteristics, and application. Crit. Rev. Food Sci. Nutr. 2019, 59, 3630-3647. [CrossRef]

48. Hill, A.; Chen, L.; Mariage, A.; Petit, J.L.; Berardinis, V.D.; Karboune, S. Discovery of new levansucrase enzymes with interesting properties and improved catalytic activity to produce levan and fructooligosaccharides. Catal. Sci. Technol. 2019, 9, 2931-2944. [CrossRef] 